\title{
An argument for reframing debates about corruption: Insights from Papua New Guinea
}

\author{
Grant W. Walton \\ Department of Resource Management and Geography, University of Melbourne, 221 Bouverie Street, Carlton 3010, \\ Australia. Email: walton.grant@gmail.com
}

\begin{abstract}
There have been few attempts to identify the way different perspectives of corruption are employed in Papua New Guinea (PNG). The paucity of such analysis makes it difficult to identify the way scholars and policy-makers understand corruption in the country, in turn leading to potentially poor targeting of anti-corruption programmes. This article categorises perspectives of corruption that are found in academic and policy accounts of PNG. It finds that this literature is marked by an over-reliance on 'mainstream' Western interpretations of the definition, causes and solutions to corruption. In turn, it is argued that there is an important role that 'critical' and culturally aware academics can play in reframing debates about corruption in PNG and the Pacific.
\end{abstract}

Keywords: alternative view, anti-corruption, corruption, mainstream view, Papua New Guinea

\section{Introduction}

Although much has been written about corruption in Papua New Guinea (PNG) and the Pacific, few authors endeavour to say what they mean when they employ the term. Moreover, there have been few attempts to categorise narratives of corruption in the Pacific, and fewer in PNG. This is problematic, for without clarity about how corruption is understood, academics, policy-makers, development workers and citizens end up talking at cross purposes about the nature of corruption, and thus how it should be addressed. Peter Larmour (2006: 17) highlights this problem by noting that the diversity of academic, official and popular conceptions of corruption in the Pacific region 'suggests there is great room for misunderstanding, irritation, and poor targeting of anti-corruption campaigns'.

Huffer (2005) provides a useful categorisation of definitions of corruption across the Pacific as opposed to PNG per se. In doing so she argues that donors understand corruption through an economic lens, which has put them at odds with the moral interpretations of local communities. As a result, she calls for local communities to lead research about communal ethics across the Pacific to help rebalance the
'Western'-centric views of anti-corruption organisations.

Using a similar, yet significantly expanded framework to Huffer (2005), ${ }^{1}$ this article imposes some order on the narratives of corruption in PNG. It does this by categorising the recent literature on corruption into two views: 'mainstream' and 'alternative'. In doing so, it finds that debates about corruption in PNG are framed, almost exclusively, by the 'mainstream' Western view of corruption. As a result, it is argued that greater attention needs to be paid to alternative conceptions of, and responses to, corruption in PNG.

The article first develops a theoretical framework for understanding the different views of corruption and anti-corruption in the international literature; it categorises the literature into mainstream and alternative views. The second section shows how these views have been presented in debates about corruption in PNG by reviewing the recent literature in PNG along with key policy documents. Section three shows how these perspectives are deployed by different actors. It argues that while the alternative view may be unpopular, it could provide important insights into the effects of anti-corruption work in the country and could show how cor- 
ruption may be better addressed. The article concludes by reflecting on how the alternative view may be encouraged and the type of questions that could guide further academic enquiry across the Pacific.

\section{'Mainstream' and 'alternative' views on corruption}

Theories about corruption abound, but a schism is growing between 'mainstream' and 'alternative' views on corruption. This section describes the way these views have been discussed in the international literature. In particular, it presents the different perspectives associated with each view, and describes how these perspectives define corruption, ascribe causation and prescribe solutions.

The framework employed here is influenced by the work of Williams (1999), Michael (2004) and Brown and Cloke (2011). Williams (1999) identified four definitions of corruption - legal, public office, economic and moral - but his discussion of these definitions is rather brief: he does not specify how they frame the way causes are ascribed and solutions prescribed to corruption. So Williams' four definitions provide a basis for fleshing out broader 'perspectives' of corruption that include definitions, causes and solutions to corruption. Michael (2004) and Brown and Cloke (2011) have identified an important 'critical school' of scholarship. Their insights have contributed to the construction of the 'alternative view'.

Table 1 summarises the taxonomy developed for this article; it shows how the mainstream and alternative views, and their associated perspectives, define, ascribe causation and prescribe solutions to corruption. It also identifies the scholars associated with these views. A description of each of these perspectives is provided below.

\section{The 'mainstream' view}

The mainstream view on corruption frames discussions about corruption in relation to the state. In this view corruption is understood in reference state laws, rules and institutions, in turn, those who reflect this view focus on the corruptibility of state officials. There are three key perspectives on corruption that align to this mainstream view. First, there is the legal perspective on corruption, which defines corruption as 'the violation of a rule' as determined by legal processes (Williams, 1999: 504). Corruption is, in this view, an act that breaches obligations set out in legal codes.

The legal perspective looks to inadequacies of the legal system to identify the causes of corruption. For example, Levin and Satarov (2000) argue that undeveloped legislation, legal loopholes, ill-defined legislative procedures and inadequate enforcement all contributed to the rise of corruption in Russia during the 1990s. Weak legal systems can result in a perpetuation of corruption, as Jain (2001: 72) illustrates:

Once corrupted, the elite will attempt to reduce the effectiveness of the legal and juridical systems through manipulation of resource allocation and appointments to key positions. Reduced resources will make it difficult for the legal system to combat corruption, thus allowing corruption to spread even more.

In turn, the legal perspective focuses on addressing corruption through the passage and tightening of laws and regulations. Practical approaches based on this perspective include international measures such as the Organisation for Economic Cooperation and Development's 1997 Convention on Combating Bribery of Foreign Public Officials in International Business Transactions and the United Nations' 2003 Convention Against Corruption. The success of these measures depends upon their ratification and effective implementation by nation states, as it is at this level that legal instruments become crucial in addressing corruption (Posadas, 2000). Thus, from the legal perspective, addressing corruption requires both the implementation and enforcement of appropriate legislation.

Academics have long looked to the law to identify corrupt behaviour (Scott, 1972). For example, Nathaniel Leff (1964), a scholar often associated with this perspective, regarded corruption as extra-legal activity. Many academics have taken Leff's lead, with Williams (1999: 504) suggesting that modern social science has favoured an 'essentially legalistic understanding of the term'. As a result, much 'debate about 


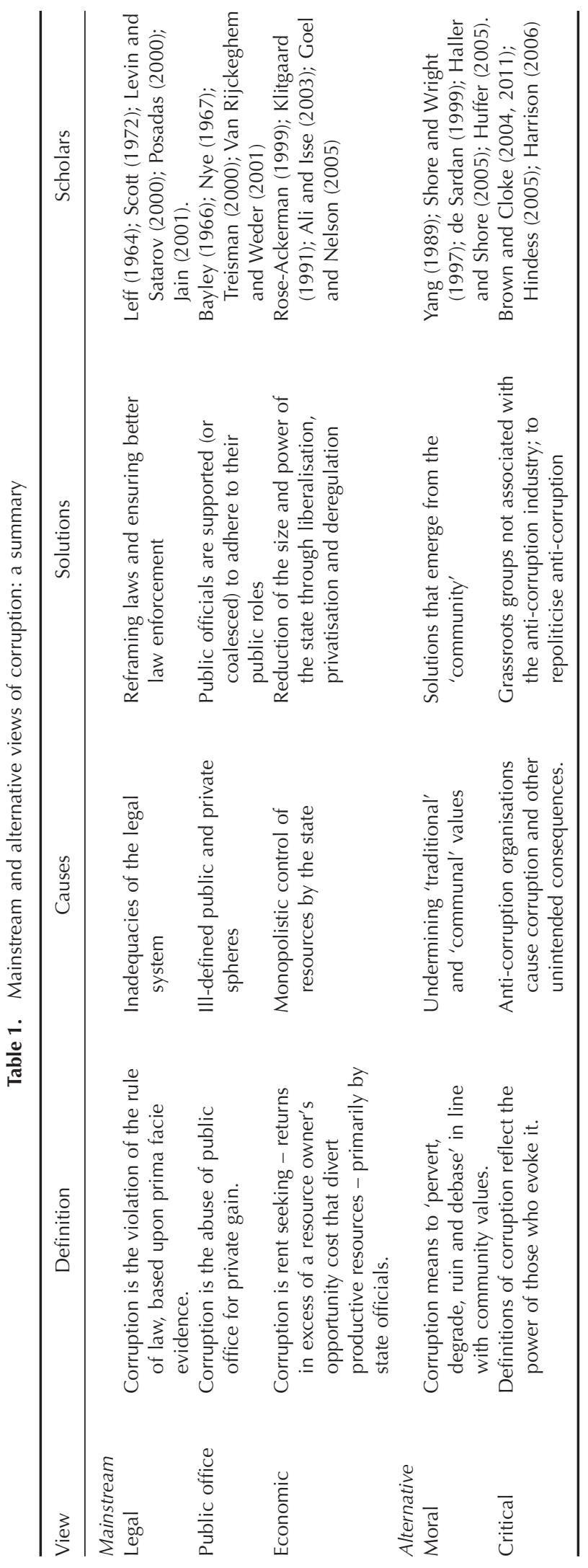


corruption is shaped by thinking in binary oppositions: corruption and the law are seen as each other's opposite' (Nuijten and Anders, 2007: 11).

The second perspective associated with the mainstream view is the public office perspective on corruption. This perspective defines corruption as 'the abuse of public office for private gain' - a definition popular with academics and policy-makers (World Bank, 1997; Treisman, 2000; Bukovansky, 2006; McClusker, 2006; Transparency International, 2010). Defined in this way, corruption has come to be connected to the way state officials execute (or fail to execute) their duties (Scott, 1972; Hutchinson, 2005).

From this perspective, causes of corruption are linked to a range of issues that give rise to public officials transgressing their official roles. Thomas and Meagher (2004) provide a useful categorisation of causes that fit under the public office perspective: they group causes of corruption into structural and individual kinds. Structural causes relate to the strength and capacity of the state. Thomas and Meagher (2004) posit that there can be no distinctive public office if the government is weak, there is no agreed public for the government to serve, and there is no clear separation between the public and the private sphere. Not having a clearly defined public office means accusations of corruption become inevitable (although problematic), as the definition of corruption from the public office perspective assumes there is an identifiable public office, and that it is segregated from the private sector and civil society.

The second categorisation identified by Thomas and Meagher (2004) are individual causes, which are concerned with the incentives that drive corruption. For example, Van Rijckeghem and Weder (2001) argue that low salaries force public servants to engage in corruption, while high salaries are a premium that are lost if they are caught and fired. Others suggest that individuals are motivated to engage in corruption if they are inadequately supervised or face insufficient sanctions (Polinksy and Shavell, 2001). So those advancing the public office perspective argue that without the right mix of (dis)incentives, corruption, particularly among public servants, will result.
Following on from the causes of corruption, solutions from the public office perspective are directed towards strengthening the state, augmenting state-society relations and changing the incentives for corrupt behaviour. The state may be strengthened through economic reform, oversight of public expenditure and financial management, support for legal and judicial systems, civil service reform and public oversight mechanisms (Michael, 2004). Statesociety reform may include the formation of anti-corruption coalitions between civil society groups and public officials. Reforms aimed at shaping individual behaviour can include internal monitoring and sanctions (through internal audit committees, reporting requirements and disciplinary codes, for example), and a broader set of positive incentives for correct behaviour (for example, increasing wages and rewarding merit-based behaviour) (Hamilton-Hart, 2001). In other words, these reforms are targeted at strengthening systems of government and coercing those working within them to do the right thing.

The public office perspective came to the fore in the 1960s and dominated the literature until the 1980s (Williams, 1999). It is linked to scholars such as Bayley (1966), Nye (1967) and Myrdal (1968), who have examined the effects of corruption on the public sector in a variety of cultural situations. Recent scholars writing from this perspective include Treisman (2000) and Van Rijckeghem and Weder (2001). Since the 1990s, in the literature on corruption, the public office perspective - while still popular - has played second fiddle to the economic perspective, the third perspective associated with the mainstream view.

The economic perspective on corruption is centrally concerned about the productive use of economic resources. For example, RoseAckerman (1999: 2) states that 'endemic corruption suggests a persuasive failure to tap self interest for productive purposes'. From this perspective corruption is often referred to as 'rent-seeking', which is defined as 'returns in excess of a resource owner's opportunity cost' (Williams, 1999: 507). While this is a broad definition, the economic perspective is centrally concerned with the potential for government to monopolise resources and demand excessive rents. 
This perspective suggests that the size of government and its level of interference in an economy are key causes of corruption. There is some evidence to support this theory. For example, Ali and Isse (2003: 461), after reviewing studies on corruption in least developed countries, find corruption is 'significantly correlated to' the size of government; their model suggests that a $10 \%$ increase in the size of government - measured as government expenditure share of gross domestic product - leads to a $2 \%$ increase in the perceived level of corruption. Similarly, Goel and Nelson (2005) examine the relationship between economic freedom (the degree of government intervention in the economy) and corruption. They argue that the less governments intervene in the economy the lower the level of perceived corruption.

Thus, reducing the monopolistic tendencies of the state and increasing competition in the private sector are key remedies advocated by the economic perspective. To achieve this, Ohnesorge (1999) suggests that governments prioritise economic deregulation, liberalisation and privatisation. These policy responses have been particularly evident in Africa during the 1990s (Szeftel, 1998). For example, Theobald (1990: 158), a supporter of such remedies, suggests that in Africa 'it may be that privatisation offers the only viable prospect of curtailing corruption'.

The economic perspective is associated with influential scholars such as Rose-Ackerman (1999) and Klitgaard (1991) who view 'government through an economic prism' (Williams, 1999: 506). For example, Rose-Ackerman (1999: xi) argues that 'economics is a powerful tool for the analysis of corruption ... . [and is] fundamental to understanding where corrupt intentions are greatest and have the biggest impact'. For these authors, economics is the lens through which corruption can be understood and offers the best tools for addressing it.

\section{The 'alternative' view}

The alternative view of corruption acknowledges that understandings of corruption depend upon community norms and relationships of power. In turn, it focuses on local responses to address corruption. There are two perspectives associated with this view - the moral perspective and the critical perspective.

From the moral perspective on corruption, corruption means to 'pervert, degrade, ruin and debase' (Williams, 1999: 504). It is a term of condemnation towards acts that are denounced by a particular community. The types of acts that are covered by this definition are culturally determined depending 'on the context and on the position of the actors involved' (de Sardan, 1999: 34). From this perspective, corruption comes into being when immoral acts benefit individuals or communities outside of the group (de Sardan, 1999), or when individuals within the community transgress communal norms for individual benefit (Skinner, 1990; Williams, 1999). Thus, corruption is a label applied to activities that a group of people disagrees with; it is not applied to activity that the group itself considers 'acceptable'.

When discussing causes of corruption, scholars of the moral perspective focus on processes that undermine 'traditional' and/or 'communal' values. For example, de Sardan (1999) argues that corruption occurs when shame, a cultural mechanism for keeping corruption in check in Africa, is undermined. Likewise, Williams (1999: 504) suggests that corruption is marked by societies that discard 'civic virtue and social responsibility' in favour of 'intense competition for spoils'. Such competition may be exacerbated by what de Sardan (1999: 45) calls 'overmonetisation', where 'personal relationships ... take on a permanent monetary form'. In Africa this includes

\footnotetext{
giving of 'taxi fare' to a visitor, giving coins to the children of friends, giving money for the purchase of a length of African print to a cousin going to a school party.

(de Sardan, 1999: 45)
}

When relationships are maintained by money this 'obliges all and sundry to engage in a permanent quest for "means" ', that is corruption becomes, for some in the community, a monetised extension of traditional gift giving (de Sardan, 1999: 46). So, for scholars who reflect the moral perspective, corruption is caused by the clash of traditional/communal and modern norms and expectations.

From this perspective, solutions to corruption should emerge from within individual 
communities. Richards (2006: 5) calls these 'community-based anti-corruption programmes', which are 'initiatives that are physically and conceptually located in a community to fight and counter corruption'. Such measures include community programmes to monitor corruption, media initiatives that shape opinions around corrupt practices and school programmes that teach appropriate norms (Michael, 2004). They stress the importance of the involvement of 'civil society' and non-governmental organisations (NGOs) to address corruption. Quite often those approaching anti-corruption from the moral perspective believe existing large-scale transnational anti-corruption organisations and institutions could better fight corruption if they incorporated local understandings in their policies and programmes (de Sardan, 1999; Huffer, 2005; Bukovansky, 2006). From this perspective, local understandings can shape anti-corruption policies and programmes to ensure their relevance within the contexts in which they operate.

The moral perspective has links to anthropological enquiry. Harrison (2006) suggests that the moral perspective has its roots in the earlier work on exchange and solidarity networks by authors such as Barth (1978), Mauss (1990) and Sahlins (1972) who - while not directly addressing corruption - explained the relational expectations that tied individuals to transactions with others. Given this, the moral perspective has been particularly popular among anthropologists who have written about corruption over the past two decades (Shore and Wright, 1997; de Sardan, 1999; Haller and Shore, 2005).

Unlike the previous perspectives, the critical perspective on corruption does not seek to define corruption per se; rather it highlights how definitions used by anti-corruption organisations marginalise competing understandings. For example, Harrison (2006: 21) argues that the 'ability to define an act as corrupt or to partake in "corrupt" activity reflects power, something that is seldom made explicit in international anti-corruption rhetoric'. So, when anti-corruption organisations suggest that one country is more or less corrupt than another, based upon their definition (or interpretation) of corruption, critical scholars suggest that this reveals the Western-centric bias of the organisations themselves, as much, if not more, than it shows anything about where corruption is manifest (Hindess, 2005; Harrison, 2006; Brown and Cloke, 2011).

The critical perspective not only focuses on the way the anti-corruption 'industry' causes corruption, but also how it causes a host of other negatives. For example, Anechiarico and Jacobs (1996) highlight the failure of anticorruption programmes in New York, suggesting that they reduced the capacity of the public administration to monitor corruption and resulted in corruption far worse than these programmes set out to prevent. For others, the anticorruption industry's solutions have transferred the problem of corruption to the private sector (de Maria, 2005; Holmes, 2006), reinforcing unequal relations between developed and developing nations (Jayasuriya, 2002).

Many evoking the critical perspective valorise solutions that stem from grassroots groups that are 'truly independent and intrinsically motivated' (Moroff and Schmidt-Pfister, 2010: 93). As a corollary, some who are critical of anti-corruption organisations fear that 'authentic' local responses will be swept away in the maelstrom of the global anti-corruption agenda. Sampson (2010: 269), for example, argues that the 'major players' (donors, governments and private NGOs) of the development industry marginalise those who question their conventional approach, thereby limiting grassroots input. What is more concerning for Sampson and others (Krastev, 2004; di Puppo 2010, Moroff and Schmidt-Pfister, 2010), however, is the tendency for grassroots movements to professionalise and mimic the activities of more established and better resourced organisations. Di Puppo's (2010) analysis of anti-corruption organisations shows that local actors working to mitigate corruption in Georgia are more accountable to foreign donors than to their domestic constituency.

In addition, some critical scholars argue that anti-corruption efforts need to be re-politicised (Hindess, 2005; Huffer, 2005; Brown and Cloke, 2011). For these scholars, the aid industry provides overly technical solutions to corruption that fail to critically address the corruption of private and public sector elites. As a result, they argue that corruption must be addressed through direct political action that confronts elites in both the state and private 
sector. For example, Hindess (2005) is critical of Transparency International ( $\mathrm{TI})$ and other agencies who view elites (particularly from the private sector) as anti-corruption champions, rather than what he believes they really are key purveyors of corruption. In turn, he argues that international anti-corruption organisations are playing along to a neo-liberal script.

There are two key strands of thought that have come to shape the critical perspective. First, there are neo-Marxist critics of (anti-)corruption who link anti-corruption activity to the social relations connected to the capitalist system (Brown and Cloke, 2004, 2005, 2006, 2011; Hindess, 2005; Murphy, 2011; Rocha et al., 2011). Second, there is a post-structuralist school (Michael, 2004), which examines the affects of anti-corruption discourse (Polzer, 2001; Harrison, 2006; Sampson, 2010). These scholars represent political scientists, anthropologists and geographers; there is a notable absence of economists writing from this perspective.

In sum, the mainstream view, as the name suggests, is more frequently represented in the literature than the alternative view. But, the alternative view, as Michael (2004) and Brown and Cloke (2011) identify, has rapidly expanded over the past decade as scholars have become increasingly attuned to the limitations of mainstream approaches to addressing corruption.

\section{Alternative and mainstream views about corruption in PNG}

There is a growing literature about corruption in PNG, but little analysis of how the term 'corruption' is employed and understood. Drawing on the taxonomy developed in the previous section, this section analyses the way scholars and policy-makers conceptualise corruption in PNG.

\section{The mainstream view}

The three perspectives of the mainstream view legal, public office and economic - are reflected in scholarship and policy documents about PNG but to varying degrees. Scholarship on PNG sometimes takes a legal perspective on corruption, with authors assuming that corruption is a subset or extension of criminal activity
(Pitts, 2001, Pitts 2002, Fallon et al., 2003). This has led to the terms 'corruption' and 'crime' being used interchangeably. For example, throughout Maxine Pitts' (2002) book Crime, Corruption and Capacity in Papua New Guinea, corruption is assumed to be a criminal act, and there is little attempt to explain how corruption is different from illegal activity.

Many also express concern that PNG's judicial system has failed to adequately curtail corruption. Pitts (2002: 172) argues that there has been much discussion in PNG about bringing those guilty of corruption to justice, but 'beyond Commissions of Inquiry, few prosecutions ensue, and even fewer perpetrators are punished, because under-resourced agencies either fail to apprehend or to prosecute criminals'. As a result, Pitts asserts that corruption by elites results in citizens feeling victimised and leads them to mimicking the illegal behaviour of their leaders in order to gain a greater share of state resources. Pitts is not alone in expressing such concerns; others such as May (2004) and Morauta (1996) have called for stricter enforcement of existing laws, particularly for highprofile politicians and public servants, in order to send a message to citizens that corruption will not be tolerated.

Current laws designed to address corruption in PNG have been deemed inadequate by many. For instance, The Commission of Inquiry Generally Into The Department of Finance (Davani et al., 2009) found numerous examples of corruption in the PNG Department of Finance; it made 75 recommendations to reduce mismanagement and corruption both in the department and across the larger bureaucracy. Some recommendations called for new laws, such as:

- [A] Whistle Blower Protection Act ... to provide legal protection for persons and public officers who report corrupt practices by public officials

- [A] Freedom of Information Act to provide clear processes to regulate access to official records and documents

- Legislation ... that promotes the use of assessors in criminal trials preparatory to eventual adoption of a system of jury trials for major crime (from Davani et al., 2009: 797-798).

These laws, the Commission believed, would help address corruption in bureaucracies across the country. 
The institutions established to reduce corruption in PNG have also been accused of failing to make significant impacts on it. The country's constitutionally mandated Ombudsman Commission (the OC PNG) has been described as under-resourced and underperforming (Okole and Kavanamur, 2003; Justice Advisory Group, 2005). As a result, some argue for the introduction of additional legal institutions, such as an Independent Commission Against Corruption (ICAC) with a wider range of investigatory powers. A draft Organic Law for an ICAC was proposed for PNG in 1997 and found support among anti-corruption organisations (Transparency International Papua New Guinea, 2009) and academics (Mana, 1999). However, to date, the draft law has not passed into legislation.

Mirroring the public office perspective on corruption, the most popular perspective taken by those writing about corruption in PNG, many are concerned that Papua New Guinean state officials fail to adequately follow due process (Dinnen, 1997; Dorney, 2001; Hughes, 2003; Gosarevski et al., 2004b). Their concerns appear well founded, with investigations into the public sector often finding examples of gross mismanagement and corruption. For instance, in a recent report into 20 government agencies, the Auditor General found many instances of poor management practices, including:

- Asset registers [that] were either nonexistent or . . . were not maintained properly in all 20 agencies

- Periodic stock-takes ... not being conducted to determine the accuracy of assets on hand in sixteen agencies

- Lack of records of portable and attractive items, i.e. mobile phones and laptops

- [Non-existent] controls surrounding management of vehicle fleets (Office of the AuditorGeneral of Papua New Guinea, 2010: 6).

Similarly, in a damning review, the Public Accounts Committee described the government's public accounting system as 'weak, corrupt and in direct breach of the Public Finances Management Act' (ABC Radio Australia, 2011). Such findings highlight the ongoing concern that corruption is caused by the inability, or unwillingness, of state officials to comply with rules and regulations.
It is often argued that the cultural and political fragmentation of PNG is a key reason for state officials transgressing rules and regulations. In PNG there is a tendency for citizens to identify with small-scale communities that are often divided along ethno-linguistic lines. In addition, there have been numerous 'micronationalist' movements - disparate groups united by their predilection towards 'disengagement or withdrawal (but not, as a rule, formal secession) from the larger, national community' (May, 2004: 49). Calls from Bougainville province and the Papuan separatist movement for secession from PNG are two of many such movements that have sprung up around the country since independence. In turn, writings about PNG stress the 'inchoate, developing character' of the nation (Robbins, 1998: 108); PNG appears to many as 'an unimagined community, a failed imitation of more established, more homogeneous Western nations' (Foster, 2002: 3). As a result, the nation-state is often subverted (Dinnen, 2001) or ignored by many in favour of sub-national affiliations.

This has consequences for practices and perceptions of corruption. According to Payani (2000), Papua New Guineans' tendency to identify with clan and community, rather than the state, has resulted in widespread nepotism in the bureaucracy. Through participant observation of administrative offices in four central government departments, Payani (2000: 143) finds that the bureaucracy has become 'ethnicised', with 'departments and agencies [dominated] by persons from a particular tribe, province, or region at the expense of others'. As a result, Payani believes segments of the state have become an extension of communities who use state power to benefit their friends, family and community. Gordon and Meggitt (1985: 181) explain how this system operates: 'once a successful politician, public servant, or entrepreneur establishes ... a bridgehead, other members of his clan exploit the entry and insert themselves in the administrative machinery'. So, the allegiance between state officials and their kith and kin are seen to enable patronage networks that facilitate corruption.

Patronage networks have also, it is argued, shaped the democratic process in PNG. Many fear that the nation has become a cliental political system where patrons (political leaders) 
provide material benefits to clients (voters/ followers) in return for political support (Kurer, 2007; Standish, 2007; Allen and Hasnain, 2010). Indeed, it is feared that the political system has come to revolve around personalities rather than parties, with charismatic politicians elected by local constituents who expect monetary rewards for their support (Kurer, 2007; Standish, 2007). There have been numerous reports about candidates distributing increasingly large sums of money and gifts to secure votes in their own village, clan or tribal grouping (Stewart and Strathern, 1998; Ketan, 2004, 2007; May, 2006; Standish, 2007). The practice has become so widespread that some believe that, for their part, citizens actively encourage this behaviour. For example, May (2004: 320) suggests that many Papua New Guineans seek 'additional compensation for land purchased earlier by the government for schools, airstrips, roads, towns, and other public facilities, and often threaten violent action if their demands are not met'. In this way, it is argued, corruption has spread, contagion-like, throughout PNG.

There is an influential, albeit smaller group of academics writing about corruption in PNG from an economic perspective on corruption. For example, Hughes suggests the government of PNG should not rely on income from largescale development projects because these projects 'create ... economic rents that provide revenues for a swollen government and public services' that fuel corruption (Hughes, 2004: 2). As a corollary, some argue that reducing the PNG government's hold over resource rents, while creating conditions for greater private sector investment, could address corruption in PNG. For example, Gosarevski et al. (2004a) believe that reducing unnecessary state regulation and opening up the economy to increased foreign direct investment deprives politicians and bureaucrats of the rents that enable corruption. It would, they argue, also result in greater opposition to corrupt transactions, implying that the private sector is less prone to corruption than the public sector.

\section{The alternative view}

The strongest advocates for the alternative view in PNG's have been mostly indigenous scholars and policy-makers, who have reflected the moral perspective on corruption. For example, Kanekane (2007) - at the time of writing the president of the PNG Media Council - suggests that Papua New Guinean customary ways result in a tolerance of corruption. He explains that voters re-elect corrupt leaders as they have a 'primordial acceptance that, although MPs have done wrong, they should be given a second chance' (Kanekane, 2007: 23). Papua New Guineans, according to Kanekane, place personal relationships before rules and laws of the state, making corruption a concept that is somewhat foreign to local culture and traditions.

Local academics have also argued for local solutions to corruption. Okole and Kavanamur (2003: 24) argue that the the dynamism and fluidity of the wantok system [a local system of obligation between kith and kin], if it can be elevated .... to the level of a civil society-wide network, would be invaluable to stem the flow of corruption'. In other words, they regard cultural systems as strengths to address corruption.

Some international academics have been sympathetic to the moral perspective. For example, Crocombe (2001) suggests that while citizens may not approve of corruption when considered abstractly, they may condone 'corrupt' acts and rationalise them if they benefit from them. This sympathetic view suggests that corruption may be a weapon of the weak in response to poverty and inequality. But, when reflecting an alternative view of corruption most international academics take a critical perspective.

Those writing from the critical perspective on corruption in PNG have focused on the Australian Agency for International Development's (AusAID) - PNG's largest donor - policies and programmes. For example, Temby (2007: 38) draws upon the work of post-development scholars to argue that AusAID's approach to good governance sidelines 'alternative and possibly more appropriate responses to the challenges facing PNG'. A few accuse AusAID of engaging in or perpetuating corruption. Tim Anderson, from the Australian-based NGO Aid Watch, argues that given the large portions of Australian aid monies returning to Australia through 'boomerang aid' (aid money that returns to its country of origin as it mostly benefits organisations and individuals of the donor nation [Aid Watch, 2005]), corruption is a term 
that should be applied to AusAID (Post-Courier, 2003). Others have suggested that AusAID's approach to development, at least in the past, has left open the potential for others to engage in corruption (Feeny, 2005; Temby, 2007). Feeny (2005), for instance, argues that AusAID shifted its approach to delivering aid money to PNG, from budget support to programmatic support, because funds provided under the previous approach were being misappropriated.

Although some have expressed concern over AusAID's good governance programme, there has been scant critique of anti-corruption NGOs and other civil society groups. In a short article, Larmour (2003) provides some insight into (rather than critique of) the operations of TI PNG. Larmour (2003) acknowledges that the impact of TI PNG's policies are difficult to assess, but is still concerned that a number of its high-profile advocacy campaigns were not sufficiently supported by politicians and the broader public. Walton (2010) compares the interactions between TI PNG and a group of local anti-corruption protesters and finds that the radical politics of the former are quelled by the discourse of the latter. While these authors do not set out to critique NGOs, they do raise questions about the 'fit' between anti-corruption strategies and local people's priorities.

\section{Reframing debates about corruption in PNG}

The taxonomy developed in this article links the unspoken connections between definitions and causes of, and solutions to, corruption to the scholars who examine this phenomenon. Examining the discourse of citizens and anticorruption organisations, however, shows how interlinked these perspectives can be. For example, AusAID presents a range of perspectives associated with the mainstream view in its 2007 anti-corruption policy paper: 'Tackling corruption for growth and development: A policy for Australian Development Assistance on Anti-Corruption' (AusAID, 2007). The paper provides a 'framework for planning, resourcing, and reviewing anti-corruption activities on a country and regional basis' (AusAID, 2007: 1). The economic perspective is evident in the document's defence of the private sector; it asserts that
While foreign companies may be targets for illicit rent seeking behavior, bribes may also appear necessary to win business. However greater transparency and international competition, and an increased awareness of the costs that corruption imposes on business, have seen the emergence of private sector champions of transparency. (AusAID, 2007: 5)

There is little mention of government efforts to correct the problem of corruption. The document also reflects the public office perspective by highlighting the importance of incentives to curb corrupt behaviour, the critical nature of the state improving budget processes, public financial management and procurement systems. While, the document broadly outlines how AusAID will help to mobilise citizens and NGOs to collect and disseminate information about the costs of corruption - an approach that reflects solutions of the moral perspective - overall, the document mostly reflects the legal, public office and economic, perspectives.

The intermingling of these perspectives also occurs in academic literature and popular narratives about corruption. In the literature on corruption in PNG this is evidenced in the writings of Papua New Guinean scholar, David Kavanamur. His discussion paper titled 'The interplay between politics and business in Papua New Guinea' (Kavanamur, 2001) reflects the economic perspective by calling for further privatisation to reduce 'rent-seeking'. An article written by Henry Okole and Kavanamur (2003), however, stresses the importance of local responses to corruption, a reflection of the moral perspective. The intermingling of these perspectives is even more apparent in public discussions about corruption in PNG. This is evidenced by responses to key political events that have triggered widespread concern about corruption (such as the Sandline Crisis of 1997 - see Dorney, (2001)), within the media and by the burgeoning community of users of social media. There is also evidence that rural communities are far from homogenous in their understandings of corruption, with recent empirical research showing that poor and marginalised citizens are more likely to define corruption from the moral perspective, with their better educated and resourced compatriots more likely to reflect the legal and public office perspectives (Walton, 2009, 2012). 
So the views and associated perspectives on corruption presented in the previous two sections are, in PNG as elsewhere, messy and dependent on institutional, cultural and historical factors. Moreover, it is important to note that authors and organisations can and do move from one perspective or view to another - and scholars need to be careful about not to over simplify the way these views and perspectives are connected to individuals and organisations. Still, there are three key trends connected to the above taxonomy that can be identified in the literature on corruption in PNG. First, as the previous section has shown, like the international literature, the mainstream view prevails in scholarship and policy documents about corruption in PNG; however, while there has been a flourishing of the alternative view in the international literature (Michael, 2004; Brown and Cloke, 2011), writings from the alternative view in PNG are flailing. In PNG, there has been little analysis of the multifaceted anti-corruption industry (apart from an examination of AusAID), nor has there been much analysis of how discourses of corruption relate to local understandings. This is surprising given the long history of anthropological inquiry in PNG - with anthropologists contributing to, if not dominating, the alternative view in the international literature.

Second, as the previous section suggests, local scholars have not only pointed out the differences between local and Western perspectives of corruption, they have also proposed local solutions to inform the fight against it. These nascent formulations of local alternatives to the mainstream view are encouraging, but it is yet to be seen as to how these views might be translated into broad-scale anti-corruption institutions and initiatives in a way that is both sensitive to local understandings of corruption, and uniform enough to meaningfully inform anticorruption policies. While major donors to PNG, like AusAID, do encourage citizens to collect and disseminate information about the costs of corruption (e.g. AusAID, 2007), there is a large divide between Okole and Kavanamur's suggestion that the wantok system should be scaled up, and the overriding concern of donors in the Pacific that mostly reflect the public office, legal or economic, perspectives (and their associated solutions) (Huffer, 2005; Hutchinson, 2005).

Third, since PNG's independence in 1975, there has been a marked shift away from seeing Papua New Guinean cultural values as a strength to fight corruption, towards seeing culture as a key cause of corruption. The dominant discourse about corruption in PNG - as represented by the mainstream view - considers cultural values, and citizens themselves, as harbingers of corruption. However, it is worth noting that this has not always been the case. Before PNG's independence in 1975, Hank Nelson wrote that

In the long term it is the people of Niugini who make one confident. They possess a courtesy, imagination and pragmatic strength to provide their own solutions. (Nelson, 1974: 230)

Such optimism is enshrined in the Constitution of PNG. Section 5(3) calls

[for] recognition that the cultural, commercial and ethnic diversity of our people is a positive strength, and for the fostering of a respect for, and appreciation of, traditional ways of life and culture, including language, in all their richness and variety, as well as for a willingness to apply these ways dynamically and creatively for the tasks of development.

Echoing this statement, in the 1980s, statesman Bernard Narokobi spoke about the importance of PNG drawing on its own traditions and Christian cosmology to develop a state that reflects the values of its citizens - described as the 'Melanesian Way' (Narokobi, 1980). When it comes to narratives about corruption in PNG in the twenty-first century, where has this optimism gone?

By the 1990s, with PNG's economy and social indicators stagnating, and with very public scandals of corruption exposed in the public sector, academics - along with the public - become overwhelmingly sceptical about Papua New Guinean cultural exceptionalism. Many came to view the 'Melanesian Way' as a thinly veiled excuse for leaders to indulge in corruption. In the early 2000s Pitts summed up this view, arguing that the 'Melanesian Way' had become 'a soft term for fraud, nepotism and cronyism that denies citizens 
their rights' (Pitts, 2002: 177). Larmour (1997: 2) highlighted this problem by noting that a previous Prime Minister of the country refuted criticism over payments he made 'to prevent a minister defecting to the opposition, by arguing that "gift giving" is part of the Melanesian political tradition'. This pessimism has likely dissuaded scholars from exploring the alternative view.

It is understandable that academics and policy-makers are cautious about writing from an alternative view, lest they provide further ammunition to elites to engage in malfeasant activities. So, it is worthwhile noting that much recent alternative scholarship seeks to increase the accountability of elites - not to excuse their actions by relativising corruption. For example, Harrison (2007: 672) argues that challenging mainstream assumptions about the nature of corruption, 'is not to present a relativistic position where, for example, corruption is relabelled as "gift giving" and thus excused as culturally acceptable'. 'Who could argue with ... the exposure of corrupt and moneygrabbing politician[s] or bureaucrats?' (Harrison, 2007: 673) she rhetorically asks. Indeed, many critical scholars argue that the existing anti-corruption industry is not focusing enough on exposing the corruption of elites. For example, Hindess (2005) argues that structural-functionalist tendency of mainstream approaches to addressing corruption placates elites, rather than calls them into account. Scholars writing from the alternative view seek to understand, and correct, what they see as the skewed nature of the narratives about corruption - not excuse the corrupt behaviour of elites.

The case for greater alternative scholarship is also strengthened when considering how well anti-corruption efforts, guided by the mainstream view, have fared to date in PNG. While a few individual anti-corruption campaigns have proved successful (e.g. Pelto, 2007), many doubt the overall effectiveness of anticorruption organisations' initiatives in the country. For example, the late Mike Manning, past chairman of the local chapter of TI PNG, wrote in its 2007 annual report that '[m]any people ask what effect does TI PNG have on the level of corruption in PNG and the answer is not very clear' (Transparency International Papua
New Guinea, 2008: 4). Local academics Okole and Kavanamur (2003: 15) suggest that, given the nature of corruption in the state, it is difficult to say whether organisations such as the OC PNG 'have made marked differences at all to deter corruption'. As Gebel (2012) suggests in her reflection on $\mathrm{TI}^{\prime}$ s global anti-corruption discourse, this does not mean we should dismiss these efforts altogether - but it does show the limitations of these mainstream approaches in PNG (and elsewhere).

Scholarship from the alternative view is not a silver bullet that will address concerns about corruption in the country. But it may help to shift thinking about corruption towards a more nuanced understanding of the issue. The broader development industry itself has a precedent for this. Critiques of the development industry in the 1990s - particularly from the post-development school (Escobar, 1992, 1995; Ferguson, 1994) - helped to shift the discourse and practice of donors and NGOs (Nederveen Pieterse, 2000; Jakimow, 2008). Policy-makers and activists can only be aided by having access to a broad range of perspectives about corruption in PNG.

\section{Conclusion}

This article suggests that to fight corruption one must first understand how it is interpreted. Through an analysis of the prevalence of alternative and mainstream views on corruption in writings about PNG, it finds that there is a dearth of scholarship from the former view. The article argues that addressing the paucity of alternative scholarship in PNG could pave the way for better understanding corruption and the anti-corruption industry in the country.

The article broadly supports Huffer's (2005) conclusion, and other scholars writing from the alternative view, that there needs to be greater appreciation of local (non-elite) perceptions of corruption. In PNG, a key challenge for academics and policy-makers in the coming years should be working out how to bridge the gap between Western and local understandings of and solutions to corruption. This process should include giving local scholars and citizens space to develop their ideas about how corruption is understood and can be meaningfully addressed. Allowing for such space and time may be diffi- 
cult for anti-corruption policy-makers, who are used to responding to corruption from a mainstream view and measuring results accordingly. But without doing so, responses to corruption will continue to miss their mark and result in frustration among policy-makers and citizens who daily read and hear about corruption but see little tangible evidence that it is being effectively combated.

In addition, this article suggests there is a need for scholars to examine the anti-corruption industry itself. This need not be criticism for criticism's sake. Rather, scholars should identify the assumptions embedded in anti-corruption policies and programmes, and explain how anti-corruption could more relevant for the contexts in which it is applied.

The case study drawn on for this article is PNG, but the findings have broader relevance they speak to a range of key issues facing many developing countries in the Pacific and elsewhere. As a result, research that seeks to address the paucity of scholarship from the alternative view across the Pacific should be seeking to answer two interrelated sets of questions. The first pertains to the moral perspective, which might include: how do citizens understand corruption; what strengths do local communities have to address corruption (and what are their limitations); how can local scholars be encouraged to publish and discuss their concerns about mainstream approaches to corruption? The second set of questions pertains to issues connected to the critical perspective. These could include the following: what are the discourses of corruption employed by anticorruption organisations and citizens; whose interests are being served by dominant discourses of corruption; what are the connections between different types of anti-corruption organisations and neo-liberalism; how do the narratives and actions of international anticorruption organisations impact on local organisations and citizens; are local perceptions of corruption being meaningfully incorporated into policy initiatives? These are only a few of the questions that demand attention from scholars. At the very least, scholars and practitioners must be aware that there are different perspectives of corruption, and how Western and local understandings of the concept shape their analysis of and responses to it.

\section{Acknowledgements}

Thanks to Professor Jon Barnett, Dr. Monnica Minnegal, and Professor Leslie Holmes who expertly supervised the thesis from which this article is partly derived. I also appreciate the valuable comments from two anonymous referees, which have strengthened this article. All mistakes remain my own.

\section{Note}

1 Huffer's (2005) adroit analysis also draws on Williams (1999) but does not set out the type of framework to analyse corruption as this article does.

\section{References}

ABC Radio Australia (2011) PNG public accounts committee criticises accounting system. http://www. radioaustralia.net.au/pacbeat/stories/201105/ s3229166.htm (last accessed 17 June, 2011).

Aid Watch (2005) Boomerang aid: Not good enough minister!: Response to Australian Foreign Minister Downer's comments on boomerang aid. Sydney: Aid Watch.

Ali, A. and H. Isse (2003) Determinants of economic corruption: A cross-country comparison, Cato Journal 22(3): 449-466.

Allen, M. and Z. Hasnain (2010) Power, pork and patronage: Decentralisation and the politicisation of the development budget in Papua New Guinea, Commonwealth Journal of Local Governance 6: 7-31.

Anechiarico, F. and J.B. Jacobs (1996) The pursuit of absolute integrity: How corruption control makes government ineffective. Chicago: University of Chicago Press.

AusAID (2007) Tackling corruption for growth and development: A policy for Australian development assistance on anti-corruption. Canberra: AusAID.

Barth, F. (1978) Scale and social organisation. Oslo: Universitetsforlage.

Bayley, D. (1966) Effects of corruption in a developing nation, The Western Political Quarterly 19(4): 719732.

Brown, E. and J. Cloke (2004) Neoliberal reform, governance and corruption in the south: Assessing the international anti-corruption crusade, Antipode 36(2): 272-294.

Brown, E. and J. Cloke (2005) Neoliberal reform, governance and corruption in Central America: Exploring the Nicaraguan case, Political Geography 24(5): 601-630.

Brown, E. and J. Cloke (2006) The critical business of corruption, Critical Perspectives on International Business 2(4): 275-298.

Brown, E. and J. Cloke (2011) Critical perspectives on corruption: An overview, Critical Perspectives on International Business 7(2): 116-124.

Bukovansky, M. (2006) The hollowness of anti-corruption discourse, Review of International Political Economy 13(2): 181-209. 
Crocombe, R. (2001) The South Pacific. Suva: University of the South Pacific.

Davani, C., M. Sheehan and D. Manoa (2009) The commission of inquiry generally into the department of finance: Final report. Port Moresby: Government of Papua New Guinea.

de Maria, W. (2005) The new war on African 'corruption': Just another neo-colonial adventure? In 4th International Critical Management Studies Conference. Cambridge University, Cambridge.

de Sardan, J.P.O. (1999) A moral economy of corruption in Africa? The Journal of Modern African Studies 37(1): 25-52.

Dinnen, S. (1997) Law, order and the state in Papua New Guinea. State, Society and Governance in Melanesia, Canberra: Research School of Pacific and Asian Studies. Canberra, Australian National University.

Dinnen, S. (2001) Law and order in a weak state: Crime and politics in Papua New Guinea. Honolulu: University of Hawaii Press.

Di Puppo, L. (2010) Anti-corruption interventions in Georgia, Global Crime 11(2): 220-236.

Dorney, S. (2001) Papua New Guinea: People politics and history since 1975. Sydney: ABC Books.

Escobar, A. (1992) Imagining a post-develoment era? Critical thought, development and social movements. Third World and Post-Colonial Issues, No. 31/32: 20-56.

Escobar, A. (1995) Encountering development: The making and unmaking of the third world. Princeton: Princeton University Press.

Fallon, J., C. Sugden and L. Pieper (2003) The contribution of Australian aid to Papua New Guinea's development 1975-2000: Provisional conclusions from a rapid assessment. Canberra: AusAID.

Feeny, S. (2005) The impact of foreign aid on economic growth in Papua New Guinea, Journal of Development Studies 41(6): 1092-1117.

Ferguson, J. (1994) The anti-politics machine: 'Development, depoliticization and bureaucratic power in Lesotho. Minneapolis, London: University of Minnesota Press.

Foster, R.J. (2002) Materialising the nation: Commodities, consumption, and media in Papua New Guinea. Bloomington: Inidiana University Press.

Gebel, A. (2012) Human nature and morality in the anticorruption discourse of Transparency International, Public Administration and Development 32(1): 109128.

Goel, R. and M. Nelson (2005) Economic freedom versus political freedom: Cross-country influences on corruption, Australian Economic Papers 44(2): 121-133.

Gordon, R.J. and M.J. Meggitt (1985) Law and order in the New Guinea Highlands: Encounters with Enga. Hanover: University Press of New England.

Gosarevski, S., H. Hughes and S. Windybank (2004a) Is Papua New Guinea viable with customary land ownership? Pacific Economic Bulletin 19(3): 133-148.

Gosarevski, S., H. Hughes and S. Windybank (2004b) Is Papua New Guinea viable? Pacific Economic Bulletin 19(1): 134-148.

Haller, D. and C. Shore (2005) Corruption: Anthropological perspectives. London: Pluto.
Hamilton-Hart, N. (2001) Anti-corruption strategies in Indonesia, Bulletin of Indonesian Economic Studies 37(1): 65-82.

Harrison, E. (2006) Unpacking the anti-corruption agenda: Dilemmas for anthropologists, Oxford Development Studies 34(1): 15-29.

Harrison, E. (2007) Corruption, Development in Practice 17(4-5): 672-678.

Hindess, B. (2005) Review essay: Investigating international anti-corruption, Third World Quarterly 26(8): 13891398.

Holmes, L. (2006) Rotten states? Corruption, postcommunism and neoliberalism. Durham and London: Duke University Press.

Huffer, E. (2005) Governance, corruption and ethics in the Pacific, The Contemporary Pacific 17(1): 118-140.

Hughes, H. (2003) Aid has failed the Pacific? The Centre for Independent Studies. No 33 http://exkiap.net/articles/ cis20030507_failed_aid/ia33.htm (last accessed 26 June 2007).

Hughes, H. (2004) Can Papua New Guinea come back from the brink? Sydney: Centre for Independent Studies.

Hutchinson, F. (2005) A review to donor agency approaches to anti-corruption. Asian Pacific School of Economics and Government Discussion Papers. Canberra: Asian Pacific School of Economics and Government, Australian National University.

Jain, A.K. (2001) Corruption: A review, The Journal of Economic Suveys 15(1): 71-121.

Jakimow, T. (2008) Answering the critics: The potential and limitations of the knowledge agenda as a practical response to post-development critiques, Progress in Development Studies 8(4): 311-323.

Jayasuriya, K. (2002) Governance, post-washington consensus and the new anti-politics, in T. Lindsey and H. Dick (eds), Corruption in Asia: Rethinking the governance paradigm, pp. 24-36. Sydney: Federation Press.

Justice Advisory Group (2005) Fighting corruption and promoting integrity in public life in Papua New Guinea. Port Moresby: Justice Advisory Group.

Kanekane, J. (2007) Tolerance and corruption in contemporary Papua New Guinea, in A. Ayius and R.J. May (eds), Corruption in Papua New Guinea: Towards and understanding of issues, pp. 23-26. Port Moresby: The National Research Institute.

Kavanamur, D. (2001) The interplay between politics and buiness in Papua New Guinea. State, Society and Governance in Melanesia Project Canberra: Research School of Pacific and Asian Studies, Australian National University.

Ketan, J. (2004) The name must not go down: Political competition and state-society relations in Mount Hagen Papua New Guinea. Suva: Institute of Pacific Studies, University of the South Pacific.

Ketan, J. (2007) The use and abuse of electoral development funds and their impact on electoral politics and governance in Papua New Guinea. CDI Policy Papers on Political Governance. Port Moresby: Centre for Democratic Institutions.

Klitgaard, R.E. (1991) Controlling corruption. Berkeley: University of California Press. 
Krastev, I. (2004) Shifting obsessions: Three essays on the politics of anticorruption. Budapest: CEU Press.

Kurer, O. (2007) Why do Papua New Guinean voters opt for clientelism? Democracy and governance in a fragile state, Pacific Economic Bulletin 22(1): 39-53.

Larmour, P. (1997) Corruption and governance in the South Pacific. State Society and Governance in Melanesia. Canberra: Australian National University.

Larmour, P. (2003) Transparency International and policy transfer in Papua New Guinea, Pacific Economic Bulletin 18(1): 115-120.

Larmour, P. (2006) Culture and corruption in the pacific islands: Some conceptual issues and findings from studies of national integrity systems. Asian Pacific School of Economics and Government: Discussion Papers. Canberra: Australian National University.

Leff, N.H. (1964) Economic development through bureaucratic corruption, The American Behavioral Scientist 8(3): 8-14.

Levin, M. and G. Satarov (2000) Corruption and institutions in Russia, European Journal of Political Economy 16: 113-132.

Mana, B. (1999) An anti-corruption strategy for provincial government in Papua New Guinea. Asia Pacific School of Economics and Government Working Papers. Canberra: Australian National University.

Mauss, M. (1990) The gift: The form and reason for exchange in archaic societies. London: Routledge.

May, R.J. (2004) State and society in Papua New Guinea: The first twenty-five years. Canberra: Australian National University E Press.

May, R.J. (2006) The 'clan vote' in Papua New Guinea: Data from Angoram, The Journal of Pacific Studies 29(1): 108-129.

McClusker, R. (2006) Review of anti-corruption strategies: Technical and background Paper. Canberra: Australian Government; Australian Institute of Criminology.

Michael, B. (2004) Explaining organizational change in international development: The role of complexity in anti-corruption work, Journal of International Development 16(8): 1067-1088.

Morauta, M. (1996) The Papua New Guinea economy: The past record, the current dilemma, the future challenge. In NCDS/NRI Conference Dinner Speech. Port Moresby.

Moroff, H. and D. Schmidt-Pfister (2010) Anti-corruption movements, mechanisms, and machines - an introduction, Global Crime 11(2): 89-98.

Murphy, J. (2011) Capitalism and transparency, Critical Perspectives on International Business 7(2): 125-141.

Myrdal, G. (1968) Asian drama: An inquiry into the poverty of nations. New York: Pantheon Books.

Narokobi, B. (1980) The Melanesian way. Boroko, Papua New Guinea: Institute of Papua New Guinea Studies.

Nederveen Pieterse, J. (2000) After post-development, Third World Quarterly 21(2): 175-191.

Nelson, H. (1974) Papua New Guinea: Black unity or black chaos? Melbourne: Penguin Books.

Nuijten, M. and G. Anders (2007) Corruption and the secret of law: An introduction, in M. Nuijten and G. Anders (eds), Corruption and the secret of law: A legal anthropological perspective, pp. 1-26. Hampshire: Ashgate.
Nye, J.S. (1967) Corruption and political development: A cost benefit analysis, American Political Science Review 61(2): 417-427.

Office of the Auditor-General of Papua New Guinea (2010) Part ii - report of the auditor-general - 2008 National Government departments and agencies: On the controls in 2009 and on transactions with or concerning the public monies and property of PNG in 2008. Port Moresby: Auditor General's Office Papua New Guinea.

Ohnesorge, J.K.M. (1999) Ratcheting up the anti-corruption drive: Could a look at recent history cure a case of theory-determinism? Connecticut Journal of International Law 14: 467-473.

Okole, H. and D. Kavanamur (2003) Political corruption in Papua New Guinea: Some causes and policy lessons, South Pacific Journal of Philosophy and Culture $7(1)$ : 7-36.

Payani, H.H. (2000) Selected problems in the Papua New Guinean public service, Asian Journal of Public Administration 22(2): 135-160.

Pelto, M. (2007) Civil society and the national integrity system in Papua New Guinea, Pacific Economic Bulletin 22(1): 54-69.

Pitts, M. (2001) Crime and corruption - does Papua New Guinea have the capacity to control it? Pacific ECOnomic Bulletin 16(2): 127-134.

Pitts, M. (2002) Crime, corruption and capacity in Papua New Guinea. Canberra: Asia Pacific Press.

Polinksy, A.M. and S. Shavell (2001) Corruption and optimal law enforcement, Journal of Public Economics 81(1): 1-24.

Polzer, T. (2001) Corruption: Deconstructing the World Bank discourse. London: Development Studies Institute.

Posadas, A. (2000) Combatting corruption under interantional law, Duke Journal of Comparative and International Law 10: 335-414.

Post-Courier (2003) PNG corruption 'simply not homegrown' Post-Courier: From: www.postcourier.com.pg/ 20030429/news09 (last accessed: 19 December 2006).

Richards, K. (2006) What works and why in communitybased anti-corruption programs. Melbourne: Transparency International Australia.

Robbins, J. (1998) On reading 'world news': Apocalyptic narrative, negative nationalism and transnational christianity in a Papua New Guinea society, Social Analysis 42(2): 103-130.

Rocha, L.J., E. Brown and J. Cloke (2011) Of legitimate and illegitimate corruption: Bankruptcies in Nicaragua, Critical Perspectives on International Business 7(2): 159-176.

Rose-Ackerman, S. (1999) Corruption and government: Causes, consequences and reform. New York: Cambridge University Press.

Sahlins, M. (1972) Stone age economics. London: Routledge.

Sampson, S. (2010) The anti-corruption industry: From movement to institution, Global Crime 11(2): 261278.

Scott, J.C. (1972) Comparative political corruption. Englewood Cliffs, New Jersey: Prentice-Hall. 
Shore, C. and S. Wright (1997) Policy a new field of anthropology, in C. Shore and S. Wright (eds), Anthropology of policy: Critical perspectives on governance and power, pp. 3-42. London and New York: Routledge.

Skinner, Q. (1990) The republican ideal of political liberty, in G. Bock (ed.), Machiavelli and republicanism, pp. 293-309. Cambridge: Cambridge University Press.

Standish, B. (2007) The dynamics of Papua New Guinea's democracy: An essay, Pacific Economic Bulletin 22(1): 135-156.

Stewart, P.J. and A.J. Strathern (1998) Money, politics, and persons in Papua New Guinea, Social Analysis 42(2): 132-149.

Szeftel, M. (1998) Misunderstanding African politics: Corruption and the governance agenda, Review of African Political Economy 25(76): 221-240.

Temby, S. (2007) Good governance in Papua New Guinea: An Australian agenda. School of Social and Environmental Enquiry Research Papers. Melbourne: The University of Melbourne.

Theobald, R. (1990) Corruption, development and underdevelopment. Basingstoke: Macmillan.

Thomas, M.A. and P. Meagher (2004) A corruption primer: An overview of concepts in the corruption literature. College Park: IRIS Center.

Transparency International (2010) Corruption perceptions index 2010. Berlin: Transparency International.
Transparency International Papua New Guinea (2008) Annual report 2007. Port Moresby: Transparency International Papua New Guinea.

Transparency International Papua New Guinea (2009) Annual report 2008. Port Moresby: Transparency International Papua New Guinea.

Treisman, D. (2000) The causes of corruption: A crossnational study, Journal of Public Economics 76(3): 399-457.

Van Rijckeghem, C. and B. Weder (2001) Bureaucratic corruption and the rate of temptation: Do wages in civil service affect corruption, and by how much? Journal of Development Economics 65(2): 307-331.

Walton, G. (2009) Rural peoples' perceptions of corruption in Papua New Guinea. Port Moresby: Transparency International Papua New Guinea.

Walton, G. (2010) A comparison of two Papua New Guinean anti-corruption agencies and their politics. The University of Melbourne Working Papers in Development, 3 / 2010.

Walton, G. (2012) Comparing local and international perspectives on corruption in Papua New Guinea. The Department of Resource Management and Geography. Melbourne: The University of Melbourne.

Williams, R. (1999) New concepts for old? Third World Quarterly 20(3): 503-513.

World Bank (1997) Helping countries combat corruption: The role of the World Bank. Washington: World Bank. 